\title{
A Review on Solid State Hydrogen Storage Material
}

\author{
Prabhukhot Prachi R. ${ }^{1, *}$, Wagh Mahesh M. ${ }^{1}$, Gangal Aneesh C. \\ ${ }^{1}$ Department of Technology, Shivaji University, India \\ ${ }^{2}$ GHARDA Institute of Technology, Mumbai University, India
}

Copyright $\mathrm{O} 2016$ by authors, all rights reserved. Authors agree that this article remains permanently open access under the terms of the Creative Commons Attribution License 4.0 International License

\begin{abstract}
Hydrogen fuel provided via green method is renewable and environmentally friendly. However, the lack of practical storage methods has restricted its use to such an extent that hydrogen storage is currently a crucial obstacle in the development of a hydrogen economy. For mobile applications hydrogen storage system needs to be lightweight and compact. Current technologies such as compressed gas or liquefied hydrogen have severe disadvantages especially in volumetric terms compared to fossil fuels and the storage of hydrogen in light weight solids could be the solution to further enhances the energy density of hydrogen tanks. This paper reveals overview of novel solid hydrogen storage materials, highlighting their main advantages and drawbacks.
\end{abstract}

Keywords Solid State Hydrogen Storage, Hydrides, Nanoparticles, Hydrogen Sorption Properties

\section{Introduction}

The top and the most debated issue in the current world scenario is energy with a wide range of choices available in terms of fuel sources and technologies available. The major economics in the world are expanding and the energy requirements of most of the nations are growing at a faster rate. The need is to sustain the economic growth at the same time to manage the green house gas emissions. In fact the two major global concerns are depleting fossil fuels and climatic change. Among all the sectors like industrial, residential, transportation, heating etc. the sector that is most affecting with depleting fossil fuel reserves is transportation system is mainly based on fossil fuels. At present, oil with a share of more than one third in the global primary energy mix, is still the largest primary fuel and covers more than $95 \%$ of the energy demand in the transport sector. Unfortunately, the combustion of hydrocarbon fuels for transportation and heating contributes over half of all greenhouse gas emissions and a large fraction of air pollutant emissions. Thus today's world is facing urgency in developing alternative fuels. Among the different alternatives available, hydrogen as a fuel offers the highest potential benefits in terms of diversified supply and reduced emissions of pollutants and greenhouse gases. As we know the key criteria for any fuel is its inexhaustibility, cleanliness, conveniences and independence from foreign control. Hydrogen posses all these properties and is well suited for both transportation and applications.

It is considered that hydrogen is going to fuel the next generation vehicles. At the same time it is also thought that the conventional engine will be replaced by a Polymer Electrolyte Membrane Fuel Cell (PEMFC). PEMFC converts chemical energy of hydrogen directly into electrical energy unlike an engine which converts chemical energy into heat and then heat into mechanical energy. Hydrogen fuel provided by green method is renewable and environmentally friendly. But the storage of hydrogen is the main obstacle in its use. Conventionally hydrogen is stored as compressed gas or as a cryogenic liquid. This kind of storage requires lot of space and bulky storage system. But for mobile application hydrogen storing system needs to be lightweight and compact. To achieve this goal much attention is currently being given to storing hydrogen in solid state materials.

\section{History}

For mobile application an efficient energy carrier is needed that can be produced and used in closed cycle. Hydrogen is the only energy carrier that can be produced easily in large amounts and in an appropriate time scale. Electric energy, either from renewable energies can be used to produce hydrogen from water by electrolysis. To achieve a driving range of $500 \mathrm{~km}$ for conventional vehicle with today's Diesel technology requires a tank system weighing approx. $43 \mathrm{~kg}$ with a volume of $46 \mathrm{~L}$. a zero-emission vehicle driven by fuel cell with hydrogen will need a 700 bar high pressure tank system of about $125 \mathrm{~kg}$ and $260 \mathrm{~L}$ to achieve the same driving range. The refueling of the high pressure hydrogen vessel will take about $3 \mathrm{~min}$, which is almost same as the Diesel tank. A hydrogen storage system for this driving range will cost about 3000 US \$ if produced in high volumes ${ }^{[1]}$. 
In hydrogen based system it is expected that a fuel cell takes hydrogen from solid state hydrogen storage device and in an electrochemical reaction it generates electricity and water is formed as a byproduct. PEMFC has a polymer electrolyte membrane which needs humidification for its functioning and therefore cannot perform at the temperature above $1000 \mathrm{C}$ and hence a fuel cell should operate at around $100^{\circ} \mathrm{C}{ }^{[2] .}$ Also the water coming out of the fuel cell is at about $90^{\circ} \mathrm{C}$ and its heat can be utilized to release hydrogen from the solid state storage device.

The transition from petroleum based energy economy to hydrogen based energy economy is a major challenge today. Particularly, for a fuel cell vehicle, storing sufficient amount of hydrogen on board of vehicle is a key issue. Hydrogen storage system is required to have high gravimetric as well as volumetric energy density to make hydrogen based vehicular applications techno-economically viable. Conventionally, hydrogen is stored as compressed gas in high pressure cylinders or as a cryogenic liquid in cryogenic containers. Both these methods being energy intensive as well as due to safety issues hydrogen storage in the form of solid compounds is considered to be a promising option..

In solid state storage option hydrogen is stored either in form of hydrides (Metal Hydrides, Complex Hydrides and Chemical Hydrides) or molecular hydrogen adsorbed on the solid surfaces. This hydrogen can be released whenever required by thermal stimulation or any other technique. Hydrogen contents of the solid, its hydrogen sorption and dehydrogenation properties, pressure and temperature of hydrogenation and dehydrogenation and the kinetics of reaction are the important parameters from subject viewpoint.

\section{Hydrogen as Fuel}

Hydrogen possesses several advantages that make it an ideal candidate to fuel our future energy needs. It is the lightest element, most abundant, non-polluting i.e. the combustion product is water, can be produced from a large variety of sources. Use of hydrogen as a fuel will not only reduce our dependence on fossil fuels but will enable energy security at the same time will take care of climate change issue. Hydrogen is in fact the lightest of all molecules (molecular weight $=2.016$ ) and, consequently, has a density of only $0.0899 \mathrm{~kg} / \mathrm{m}^{3}$ at normal temperature $(272.150 \mathrm{~K})$ and pressure $(101.325 \mathrm{kPa})$ i.e. $7 \%$ of the density of air. Liquid hydrogen also has a low density of $70.8 \mathrm{~kg} / \mathrm{m}^{3}$ (7\% of that of water). The liquid hydrogen has a very low boiling point $(20.3 \mathrm{~K})$ and thus requires fairly sophisticated technology to prepare and maintain in this state. By virtue of exceptionally low density, hydrogen has the best energy to weight ratio (heating value) of any fuel, but its energy to volume ratio is poor. The higher heating value of hydrogen is $141.78 \mathrm{MJ}$ per $\mathrm{kg}$ of $\mathrm{H}_{2}$ and its lower heating value is $120 \mathrm{MJ}$ per $\mathrm{kg}$ of $\mathrm{H}_{2}$. A comparison of properties of hydrogen against the other fuels is made in the table 1.

Hydrogen burns cleanly in air, water is the only product. It has widely flammability range. Since the lower explosive limit of hydrogen in air ( $13 \%$ by volume) is higher than the lower flammability limit, hydrogen generally burns rather than explodes. The flame velocity of hydrogen is much higher than that of conventional gaseous fuels. When mixed with pure oxygen in a 2:1 molecular ratio of hydrogen to oxygen and ignited, hydrogen detonates violently since there is no inert nitrogen to slow down the wave front. The energy required to ignite a hydrogen air mixture is very low only $0.02 \mathrm{MJ}$, and is about one-fourteenth of the energy needed to ignite natural gas. The combination of all these physical properties of hydrogen (like low density, low boiling point, wide flammability range, low ignition energy, high diffusivity in air, high flame velocity) is unique among all fuels, and this combination has safety implications for the use of hydrogen in bulk. But the low density and high diffusivity in air means that in case of any leakage hydrogen will disperse off very fast. Besides hydrogen has very high calorific value, with the LHV of $120 \mathrm{MJ} / \mathrm{kg}$ compared with petrol, which approximately one-third of this i.e. $43 \mathrm{MJ} / \mathrm{kg}$.

The distinctive properties of hydrogen make it unique fuel. Hydrogen can be used for power generation either by combustion in IC engine, producing mechanical power, or electrochemically by using a fuel cell, producing electrical power. In both these cases, hydrogen reacts with oxygen to produce water. In case of fuel cell the only water, but for ICE if the combustion is at very high temperatures NOX is also formed as such ICE must run with lean mixtures to avoid this. Although hydrogen is very abundant but it does not exist in elemental form, rather is found in combination with other elements to form either hydrocarbons or water. Hydrogen can be produced from these by electrolysis, reforming, fermentation etc. If a renewable source is used hydrogen production can be free of $\mathrm{CO}_{2}$ emissions, but if produced from fossil fuels then it requires $\mathrm{CO}_{2}$ capture and sequestration. Hydrogen is thus a versatile energy carrier and is seen to play a major role in solution to lowering the $\mathrm{CO}_{2}$ emissions. Thus one sector where hydrogen is likely to have a major impact is transport because hydrogen fuel cells have a higherenergy density than current battery technologies, which severely limits the range of current electric vehicles. 
Table 1. Technical comparison of hydrogen with other fuels ${ }^{[3]}$

\begin{tabular}{|c|c|c|c|c|c|c|}
\hline & Hydrogen & Petroleum & Methanol & Methane & Propane & Ammonia \\
\hline Boiling point $[\mathrm{K}]$ & 20.3 & $350-400$ & 337 & 111.7 & 230.8 & 240 \\
\hline Liquid density $\left[\mathrm{kg} / \mathrm{m}^{3}\right]$ NTP & 70.8 & 702 & 797 & 425 & 507 & 771 \\
\hline Gas density $\left[\mathrm{kg} / \mathrm{m}^{3}\right]$ NTP & 0.0899 & ---- & ---- & 0.718 & 2.01 & 0.77 \\
\hline Heat of vaporization $[\mathrm{KJ} / \mathrm{kg}]$ & 444 & 302 & 1168 & 577 & 388 & 1377 \\
\hline Higher heating value $[\mathrm{MJ} / \mathrm{kg}]$ & 41.9 & 46.7 & 23.3 & 55.5 & 48.9 & 22.5 \\
\hline Lower heating value $[\mathrm{MJ} / \mathrm{kg}]$ & 120 & 44.38 & 20.1 & 50.0 & 46.4 & 18.6 \\
\hline $\begin{array}{l}\text { Lower heating value (liquid) } \\
\qquad\left[\mathrm{MJ} / \mathrm{m}^{3}\right]\end{array}$ & 8520 & 31170 & 16020 & 21250 & 23520 & 14350 \\
\hline Diffusivity in air $\left[\mathrm{cm}^{2} / \mathrm{s}\right]$ & 0.63 & 0.08 & 0.16 & 0.20 & 0.10 & 0.20 \\
\hline $\begin{array}{c}\text { Lower flammability limit } \\
\text { [vol\% (in air)] }\end{array}$ & 4 & 1 & 7 & 5 & 2 & 15 \\
\hline $\begin{array}{l}\text { Higher flammability limit } \\
\text { [vol\% (in air)] }\end{array}$ & 75 & 6 & 36 & 15 & 10 & 28 \\
\hline $\begin{array}{l}\text { Ignition temperature in air } \\
{[0 \mathrm{C}]}\end{array}$ & 585 & 222 & 385 & 534 & 466 & 651 \\
\hline Ignition energy [MJ] & 0.02 & 0.25 & ---- & 0.30 & 0.25 & ---- \\
\hline Flame velocity $[\mathrm{cm} / \mathrm{s}]$ & 270 & 30 & ---- & 34 & 38 & ---- \\
\hline
\end{tabular}

\section{Hydrogen Storage}

Hydrogen storage is an essential component and major hurdle in widespread use of hydrogen as a fuel. Use of hydrogen for stationary applications is not having many challenges as compared to mobile applications and these challenges are in terms of the low density of hydrogen. As mentioned earlier, hydrogen has a very low density of $0.089 \mathrm{~kg} / \mathrm{m}^{3}$ as such on volume basis the volume that $1 \mathrm{~kg}$ of hydrogen occupies at ambient temperature and pressure is extremely high i.e. $11 \mathrm{~m}^{3}$. In order to run a vehicle for $500 \mathrm{kms}$ between two fills the amount of hydrogen required is $5-13 \mathrm{~kg}$ depending on driving cycle and vehicle type. As such the space required to store that much hydrogen is unimaginably high as compared to today's gasoline fuelled vehicle tank size. As such the requirement is of either large compression or some other mode of storage to store hydrogen more effectively and the other possible options are liquid and solid state storage. The extremely low density of hydrogen makes the storage of hydrogen a major issue in transition to hydrogen economy. The US DOE has set tough targets for hydrogen storage for the development of hydrogen fuelled vehicles. These targets show the importance of both gravimetric and volumetric capacity of the store, as one does not want the store to be too heavy (limiting the range of the vehicle) or too voluminous (limiting the luggage space). Table 2 summarizes the DOE targets for hydrogen storage. In the following sections all the three methods of hydrogen storage viz. gaseous, liquid and solid state are described briefly.

Table 2. US DOE targets for hydrogen storage

\begin{tabular}{|c|c|c|c|}
\hline Storage parameter & Units & 2010 & 2015 \\
\hline System gravimetric capacity & $\begin{array}{c}\mathrm{kWh} / \mathrm{kg}\left(\mathrm{kgH}_{2} / \mathrm{kg}\right. \\
\text { system) }\end{array}$ & $2(0.06)$ & $3(0.09)$ \\
\hline System volumetric capacity & $\mathrm{kWh} / \mathrm{L}\left(\mathrm{kgH}_{2} / \mathrm{L}\right.$ system $)$ & $1.5(0.045)$ & $2.7(0.081)$ \\
\hline Storage system cost (and fuel cost) & $\$ / \mathrm{kWh}$ net $\left(\$ / \mathrm{kg} \mathrm{H}_{2}\right)$ & $4(133)$ & $2(67)$ \\
\hline $\begin{array}{c}\text { Durability/Operability } \\
\text { Operating ambient temperature }\end{array}$ & ${ }^{0} \mathrm{C}$ & $-30 / 50($ sun $)$ & $-40 / 60$ (sun) \\
\hline Min/Max delivery temperature & ${ }^{0} \mathrm{C}$ & $-40 / 85$ & $-40 / 85$ \\
\hline Cycle life $\left(1 / 4^{\text {th }}\right.$ tank to full $)$ & Cycles & 1000 & 1500 \\
\hline $\begin{array}{l}\text { Min. delivery pressure from tank; } \\
\text { FC=fuel cell, ICE=IC engine }\end{array}$ & Atm & $\begin{array}{c}4 \mathrm{FC} / \\
35 \mathrm{ICE}\end{array}$ & $\begin{array}{c}3 \mathrm{FC} / \\
35 \mathrm{ICE}\end{array}$ \\
\hline Max delivery pressure from tank & Atm & 100 & 100 \\
\hline $\begin{array}{l}\text { Charging/Discharging rates } \\
\text { System fill time (for } 5 \mathrm{~kg} \text { ) }\end{array}$ & Min & 3 & 2.5 \\
\hline Fuel purity & $\% \mathrm{H}_{2}$ & \multicolumn{2}{|c|}{99.99 (Dry basis) } \\
\hline
\end{tabular}

Source: http://wwwl.eere.energy.gov/hydrogenandfuelcells//pdfs/freedomcar_targets_explanations.pdf 


\subsection{Compressed Hydrogen Storage}

High compression ratio is required to store sufficient amount of hydrogen to run a vehicle for about $500 \mathrm{kms}$. Due to high pressures involved the safety of storage and integrity of the tank is an issue. High strength steel is good from strength perspective but due to high diffusivity and hydrogen embrittlement problems, the weight of the tank is high. Other options are austenitic steel or composite cylinders. Commercially available tanks are of type 3 or type 4, with a metal liner or light weight metal liner, pressure vessels commercially available are either of 5000 and 10,000 psi compressed hydrogen. A storage of $5 \mathrm{~kg}$ of compressed hydrogen at 5000 psi would require a volume of $212 \mathrm{~L}$ (or 56 gal), which is much higher than conventional vehicles. The gravimetric storage capacity of for a 700 bar tank is $4.5 \%$; however the volumetric capacity is only $0.025 \mathrm{~kg} \mathrm{H}_{2} / \mathrm{L}$ which is equivalent to $0.83 \mathrm{KW} / \mathrm{L}$. going to higher pressures will improve volumetric capacity but the energy required for 700 bar compression is $15 \%$ of LHV of hydrogen stored in the vessel and there are practical and safety concerns with refueling vehicles at 700 bars. Besides the high diffusivity, hydrogen embrittlement and high pressures in itself lay down important safety issues that need to be addressed. Conformability of the pressure vessel is another important problem.

\subsection{Liquid Hydrogen Storage}

The energy density of hydrogen can be doubled as compared to the 10000 psi compressed hydrogen to $70 \mathrm{~g} / \mathrm{L}$ by liquefaction to the temperature of $20 \mathrm{~K}$. $5 \mathrm{~kg}$ of liquid hydrogen then requires only $71 \mathrm{~L}$ of volume which is equivalent on volumetric basis to current vehicles. However the major issues with liquid state hydrogen storage are that the liquefaction process is highly energy intensive besides the boil off losses are very severe. The energy utilized for cooling to hydrogen liquid state requires an estimated $30 \%$ of the LHV of hydrogen, which is very large compared to compression energy requirements. However, well insulated containers, but within a period of time the liquid hydrogen gains heat from the surroundings and convert into gas and needs to be released to avoid excess pressure. These boil off losses are estimated to be about $4 \%$ per day for a $4.6 \mathrm{~kg}$ tank, however the losses are less in a bigger tank of higher capacity. The cryo-compressed hydrogen storage is a response to these issues, and insulated pressure vessels which are heavier than compressed hydrogen storage are used. An option is insulated pressure vessels at $20 \mathrm{~K}$ and 240 atm pressure, such prototypes have been demonstrated.

\subsection{Solid State Storage}

Thus the high pressure compressed hydrogen storage has issues with respect to the strength of material, safety of the tank and finally the tank weight, while the issues with liquid hydrogen storage are the boil off loss and the energy requirements for liquefaction. However, both these issues are addressed in solid state hydrogen storage where hydrogen combines either physically or chemically with some of the materials to give hydrides and hydrogen can be obtained whenever required by either thermal stimulation or some other technique like hydrolysis. Hydrogen can be stored in solid state either as physically bound hydrogen. In case of physically bound hydrogen the hydrogen gas is physisorbed to a high surface area substrate, while in chemically bound hydrogen the hydrogen forms a chemical compound with the substrate (e.g. metal hydrides and complex hydrides) and the hydrogen is released through a thermal decomposition route. Hydrogen sorption and desorption characteristics of various materials have been studied that include zeolites, metal organic frameworks (MOFs) and carbon nano tubes (CNTs) undergoing chemisorptions. Recently the focus has been shifted to the complex and chemically hydride that contain large quantity of hydrogen.

\section{Mechanisms of Solid State Hydrogen Storage- Overview of Literature}

Hydrogen can combine with solids either physically or chemically. The two mechanisms of solid state hydrogen storage are therefore called physisorption and chemisorptions respectively. In physisorption hydrogen molecule sticks to the solid surface where as in chemisorptions hydrogen chemically reacts with the solid forming a hydride. Both the mechanisms of solid state hydrogen storage are discussed in the following sections. Also the materials are also discussed.

\subsection{Physically Bound Hydrogen}

Hydrogen like any other gas, physisorbs onto a surface, the diatomic molecule does not dissociate and is held to the surface through weak van der waals interactions. The strength of these interactions for hydrogen is very weak with the enthalpy of adsorption $\Delta \mathrm{H}_{\mathrm{a}}$ between 4 and $10 \mathrm{KJ} / \mathrm{mol}$. These weak interactions suggest that low temperatures are needed to obtain significant amount of hydrogen gas adsorbed. Physisorption is a surface phenomenon, thus high surface area materials have been well researched. As per the requisites of mobile applications it possesses no hydrogen loss during adsorption and desorption and very fast kinetics as no activation energy involved. Porous materials which have received considerable attention includes high surface area carbon structures, carbon nanotubes (CNT), metal organic frameworks (MOF), zeolites and more recently polymers of intrinsic porosity (PIMs).

\subsubsection{Carbon Nanotubes and Other Carbon Structures}

Single wall carbon nanotubes (SWNTs), multi wall nanotubes (MWNTs) and other carbon structures viz. graphitic nanofibers (GNFs), carbon aerogels (CAs), carbon nanorods etc. have received a lot of attention over the past 
decade from the hydrogen storage viewpoint. All these materials consist of benzene like carbon hexagons but differ from each other in terms of the arrangement of these hexagons. These materials can be classified broadly into two categories: those possessing long range order of carbon hexagons namely carbon nanotubes and nanofibers and those having irregular structures like activated carbon.

An extensive worldwide surge of research in the area of carbon nanotubes started in late nineties when it was proposed that CNTs and GNFs can store upto $67 \mathrm{wt} \%$ of hydrogen ${ }^{[4,5]}$. After that many succeeding experiments were carried out with different carbon structures, but such high values have not yet been reproduced by any other groups. In fact there is no theoretical basis that could support the unusually high storage capacities reported and the high storage capacity results were more related to the faults of experiment ${ }^{[6,7]}$. Nevertheless, carbon materials are still an attractive option as far as hydrogen storage is concerned. On the basis of experimental investigations it was proposes that the amount of adsorbed hydrogen is proportional to the specific surface area of the carbon materials ${ }^{[8,9]}$. Zhou et al. 2004 reported that activated carbons and activated carbon fibers can store $5 \mathrm{wt} \%$ of hydrogen at low temperature $(77 \mathrm{~K})$ and high pressure (30 to $60 \mathrm{bar})^{[10]}$. Hydrogen capacity of 7 $\mathrm{wt} \%$ is observed at $77 \mathrm{~K}$ and $20 \mathrm{bar}$ for ordered porous carbon with surface area of $3200 \mathrm{~m}^{2} / \mathrm{g}$, prepared by template ${ }^{[11]}$. Recent studies on carbon aerogels (CAs), another class of amorphous pours carbon structures with high surface area, shows $5 \mathrm{wt} \%$ of hydrogen adsorption for surface area of $3200 \mathrm{~m}^{2} / \mathrm{g}$ at $77 \mathrm{~K}$ and pressure $20-30 \mathrm{bar}^{[12]}$. In gen it is stated that for GNF, SWNT, and MWNT, the reversible hydrogen uptake of $1.5 \mathrm{wt} \%$ per $1000 \mathrm{~m}^{2} / \mathrm{g}$ of specific area is achievable under ambient conditions ${ }^{[13]}$.

The experiments carried out on CNTs report different hydrogen storage capacities for CNTs prepared by different methods. Hydrogen uptake capacity of $2.5 \mathrm{wt} \%$ has been reported for MWNTs synthesized by decomposition of $\mathrm{C}_{2} \mathrm{H}_{2}$ followed by acid purification. Experiments were carried out at 80 bar pressure and room temperature and it took 12 hours for the said hydrogen uptake ${ }^{[14]}$. Possibility of enhancing the hydrogen stirage capacity by activating CNTs and/or by using catalyst has been explored by many. Activation of MWNTs with $\mathrm{KOH}$ solution resulted in increase in the surface area from 64.8 to $830 \mathrm{~m}^{2} / \mathrm{g}$ due to increase in the porosity and core volume of the tubes ${ }^{[15]}$. Boron doped CNTs showed a maximum of $2 \mathrm{wt} \%$ hydrogen storage capacity at 80 bar pressure, whereas the pure carbon nanotubes showed only $0.6 \mathrm{wt} \%{ }^{[16]}$. Hydrogen storage capacity of palladium nanoparticles doped CNTs were found to be only $0.35 \mathrm{wt} \%$ at 26 bar and $298 \mathrm{~K}^{[17]}$. On the contrary at low temperature $(80 \mathrm{~K})$ gravimetric hydrogen storage capacity of high purity SWNTs was observed to be $8.25 \mathrm{wt} \%$ at 70 bar pressure ${ }^{[18]}$. Opposite to this encouraging result other reports regarding hydrogen storage capacity at low temperature showed $0.5 \mathrm{wt} \%$ in case of CNTs and $3 \mathrm{wt} \%$ in case of activated carbon at $77 \mathrm{~K}^{[19]}, 0.7 \mathrm{wt} \%$ for acid treated CNTs at $253 \mathrm{~K}$ and 60 bar $^{[20]}$ and $3.27 \mathrm{wt} \%$ for acid treated
MWNTs at $77 \mathrm{~K}$ and 120 bar ${ }^{[21]}$. It can be seen from the experimental results reported in the literature that none of the results are consistent with others and this may be due to the variety of synthesis procedures available for synthesis of carbon structures and CNTs in particular.

Research shows that for all micro porous carbon materials the hydrogen storage capacity is proportional to the specific surface area or the pore volume of the micropores at both 77 $\mathrm{K}$ and room temperature ${ }^{[70,71,72]}$.As such there are many parameters involved in the synthesis processes and a little variation can affect the quality of the CNTs produced, the specific surface area and consequently the hydrogen storage capacity. Although the reversibility and fast kinetics make these materials attractive options, low hydrogen storage capacity at ambient conditions and the need of cryogenic temperature for high hydrogen storage capacity puts a major limitation on the use of these carbon structures as far as the practical application is concerned. Carbon materials are often used as support materials due to their low price, chemical inertness, high thermal stability in inert atmosphere and low weight and also effective heat conduction ${ }^{[1]}$.

\subsubsection{Zeolites}

Zeolites are three dimensional aluminosilicate structures built of $\mathrm{TO}_{4}$ tetrahedrons sharing all four corners, where $\mathrm{T}$ indicates $\mathrm{Si}^{4+}$ and $\mathrm{Al}^{3+}$ ions. They are crystalline and their general formula can be written as $\mathrm{M}_{\mathrm{X} / \mathrm{Z}}\left[\left(\mathrm{AlO}_{2}\right)_{\mathrm{X}}\left(\mathrm{SiO}_{2}\right)_{\mathrm{y}}\right] \mathrm{mH}_{2} \mathrm{O}$, where $\mathrm{M}$ is non framework exchangeable cation. This exchangeable cation $\mathrm{M}$ is usually alkali or alkaline earth metal ion. Zeolites can have a very open micro porous structure with different framework types depending on the assembly of the tetrahedral building units. The adsorption characteristics of zeolites make them attractive candidates for gas storage, and therefore, taking this property into account; zeolites have been studied as potential hydrogen storage materials.

Zeolites are being studied for hydrogen storage applications for last several years. However the gravimetric hydrogen storage capacity is quite less for these materials. At room temperature less than $0.1 \mathrm{wt} \%$ hydrogen uptake capacity has been reported for different zeolites ${ }^{[22]}$. Hydrogen uptake can be increased by reducing the temperature from room temperature to $77 \mathrm{~K}$. it has been shown that for $\mathrm{NaY}$ zeolite maximum gravimetric hydrogen storage capacity of $1.81 \mathrm{wt} \%$ can be obtained at pressure and temperature of 15 bar and $77 \mathrm{~K}$ respectively ${ }^{[23]}$. A maximum of $2.19 \mathrm{wt} \%$ was obtained for CaX zeolite at 15 bar pressure and $77 \mathrm{~K}$ temperature ${ }^{[24]}$. Theoretical calculations show that the maximum possible gravimetric hydrogen storage capacity of zeolite is limited to $2.86 \mathrm{wt} \%{ }^{[25]}$.

The cation present in the zeolite framework plays an important role in the interaction of hydrogen molecule with zeolite. Specific interaction between hydrogen molecule and the cation takes place and the interaction increases with the polarizing potential of the cation present in the framework. However these strong binding sites saturate at low hydrogen concentration and thus these cationic centres has meager 
effect on the hydrogen storage capacity at high pressures. Surface area is the only parameter influencing the number of adsorption sites ${ }^{[26]}$.

Zeolite although offer flexibility over the possible framework geometries, their use as hydrogen storage materials is restricted by the theoretical upper limit on the hydrogen storage capacity and the need of cryogenic temperature for achieving high storage capacity. They offer the same advantage and drawbacks as that of carbon structures.

\subsubsection{Metal Organic Frameworks (MOFs)}

Metal organic frameworks (MOFs) represent a new category of synthetic nanoporous material consisting of organic ligands connecting metal ions or clusters that form a cage structure. Most MOFs have a three-dimensional interconnected porous framework with uniform pores that provides an ordered network of channels. The main characteristic of MOFs is usually in the range of 500-3000 $\mathrm{m}^{2} / \mathrm{g}$ while values higher than $5000 \mathrm{~m}^{2} / \mathrm{g}$ are also attainable ${ }^{[27]}$. Due to their large surface area their use for hydrogen storage application was proposed.

In the year 1999 the use of MOFs materials as a medium for hydrogen storage was reported for the first time by Li et al. ${ }^{[28]}$. Hydrogen storage properties of MOF-5, a cubic three dimensional structure with $\mathrm{Zn}_{4} \mathrm{O}$ nodes at each corner of a cube coordinated by six terephthalate ions were investigated and it was found that MOF-5 shows a hydrogen storage capacity of $4.5 \mathrm{wt} \%$ at the temperature and pressure of $77 \mathrm{~K}$ and 0.8 bar respectively, whereas its capacity at room temperature and at a pressure of $20 \mathrm{bar}$ was almost $1 \mathrm{wt} \%$. After this first report MOF-5 was widely studied and various groups reported various result. Maximum hydrogen uptake of MOF- 5 was observed to be $1.32 \mathrm{wt} \%$ at 1 bar and $77 \mathrm{~K}$ by Roswell et al. ${ }^{[27]}$. Gravimetric hydrogen storage capacity of $1.6 \mathrm{wt} \%$ was reported for MOF-5 at pressures above 10 bar. It was also reported that the adsorption capacity of MOF-5 was very low at room temperature, with values of less than $0.2 \mathrm{wt} \%$ even at high pressure up to $67 \mathrm{bar}{ }^{[29]}$. It was observed that the procedure followed for synthesis of MOF-5 affects greatly the hydrogen storage properties of MOF-5. When prepared in complete absence of moisture and air MOF-5 showed high gravimetric hydrogen storage capacity of $7 \mathrm{wt} \%{ }^{[30]}$. Due to low density of MOFs the total volumetric hydrogen storage capacity of MOFs get affected ${ }^{[31]}$. However a group from BASF showed that the MOF-5 and IRMOF-8 (Isoreticular Metal Organic Framework) exhibit higher volumetric hydrogen storage capacity at $77 \mathrm{~K}$ when compared with pressurized empty container filled with hydrogen ${ }^{[32]}$.

Other that MOF-5 many other MOFs were studied for hydrogen storage. The MOF-177, which consists of $\mathrm{Zn}_{4} \mathrm{O}\left(\mathrm{CO}_{2}\right)_{6}$ clusters, coordinated by the tritopic linker BTB (benzene tribenzoate) ${ }^{[33]}$, showed hydrogen storage capacity of $7.5 \mathrm{wt} \%{ }^{[34,35]}$. This value is higher than for any other porous material which adsorbs hydrogen in the molecular form. Similarly, for two MOFs having an NbO-type framework topology and consisting of $\mathrm{Cu}(\mathrm{II})$-dimeric paddle-wheel units coordinated by terphenyl and quaterphenyl connectors the hydrogen storage capacity of 6.7 and $7 \mathrm{wt} \%$ were reported ${ }^{[36]}$. It was also shown that a direct correlation exists between the maximum hydrogen storage capacity of MOFs at $77 \mathrm{~K}$ and their specific $\operatorname{area}^{[29,34]}$.

So far the MOFs have shown the highest hydrogen storage capacity of $7.5 \mathrm{wt} \%$ at $77 \mathrm{~K}$. a direct correlation between specific surface area and hydrogen storage capacity puts a demand for large surface area materials for high hydrogen contents. Sensitivity to the synthesis process and the atmosphere and need of cryogenic temperature puts a big question mark for their use as practical hydrogen storage material.

Recent results have shown that the surface area alone does not determine the capacity; the pore geometry and pore volume are equally important. These porous materials show excellent cyclability as the material itself does not undergo any changes during adsorption or desorption processes. Also the rate at which hydrogen can be released from these materials is also fast as such possessing better kinetics, but the requirement of cryogenic temperature is the major hurdle. The need of cryogenic temperatures can be overcome if the hydrogen is coordinated more strongly with the substrate, with the ideal enthalpy of interaction being about $30 \mathrm{KJ} / \mathrm{mol}$ for storage at room temperature. This is much stronger than physisorption, as such requires hydrogen molecule either bonded to an active metal site or spill-over effect.

\subsubsection{Organic Polymers}

It is initially reported that hydrogen uptake capacities of Polyaniline (PAni) and polypirrole (Ppy) at room temperature is of $6-8 \mathrm{wt}^{\left[{ }^{[73,74]}\right.}$. After further research it is concluded that previous results are false and capacity is less than $0.5 \mathrm{wt} \%$ at room temperature and pressure up to 94 bar. The material is attraction of study as they consists of very light atoms $(\mathrm{C}, \mathrm{H}, \mathrm{N}$, and $\mathrm{O})$ and possess high specific surface area and controlled porosity. Budd et al. showed that hydrogen uptake increases with higher concentration of ultramicroporoes at low pressure and temperature of $77 \mathrm{~K}$ [75].

PIM stores up to $2.7 \mathrm{wt} \%$ at $77 \mathrm{~K}$ and 10 bar with subunit triptycene ${ }^{[75,76]}$. Further modification leads to enhancing their hydrogen storage capacity at cryogenic temperature.

\subsection{Chemically Bound Hydrogen}

Hydrogen molecule when comes in contact with the solid surface, it dissociates into two hydrogen atoms which diffuse in the solid and form a chemical bond with the solid material. This phenomenon is known as chemisorptions. The classic chemically bound hydrogen storage materials are the metal hydrides. Most of the metals and alloys react reversibly with hydrogen to form hydride. Hydrogen forms metal hydrides with some metals and alloys leading to solid state storage under moderate temperature and pressure that gives them the 
important safety advantage over the gaseous and liquid storage methods. Metal hydrides have higher hydrogen-storage density $\left(6.5 \mathrm{H}\right.$ atoms $/ \mathrm{cm}^{3}$ for $\left.\mathrm{MgH}_{2}\right)$ than hydrogen gas $\left(0.99 \mathrm{H}\right.$ atoms $\left./ \mathrm{cm}^{3}\right)$ or liquid hydrogen $(4.2 \mathrm{H}$ atoms $/ \mathrm{cm}^{3}$ ). Hence, metal hydride storage is a safe, volume-efficient storage method for on-board vehicle applications.

These are two possible ways of hydriding a metal, direct dissociative chemisorptions and electrochemical splitting of water. These reactions are:

$$
\begin{gathered}
M+\frac{x}{2} H_{2} \leftrightarrow M H_{x} \\
M+\frac{x}{2} H_{2} O+\frac{x}{2} e^{-} \leftrightarrow M H_{x}+\frac{x}{2} O H^{-} \\
\text {M represents the metal }
\end{gathered}
$$

Metal hydrides compose of metal atoms that constitute a host lattice and hydrogen atoms. Metal and hydrogen usually form two different kinds of hydrides, $\alpha$-phase at which only some hydrogen is absorbed and $\beta$-phase at which hydride is fully formed. Hydrogen storage in metal hydrides depends on different parameters and consists of several mechanistic steps. Metals differ in the ability to dissociate hydrogen, this ability being dependent on surface structure, morphology and purity. An optimum hydrogen storage material is required to have the following properties; high hydrogen capacity per unit mass and unit volume which determines the amount of available energy, low dissociation temperature, moderate dissociation pressure, low heat of formation in order to minimize the energy necessary for hydrogen release, low heat dissipation during the exothermic hydride formation, reversibility, limited energy loss during charge and discharge of hydrogen, fast kinetics, high stability against $\mathrm{O}_{2}$ and moisture for long cycle life, cyclability, low cost of recycling and charging infrastructures and high safety. The light metals such as $\mathrm{Li}, \mathrm{Be}, \mathrm{Na}, \mathrm{Mg}, \mathrm{b}$ and $\mathrm{Al}$ form a large variety of metal-hydrogen compounds. They are especially interesting due to their light weight and the number of hydrogen atoms per metal atom, which is in many cases at the order of $\mathrm{H} / \mathrm{M}=2$. Heavier ones may enter the multiple component system only as a low abundant additive, most likely for alteration of properties or as a catalyst. There is enduring research both on modifying and optimizing the known hydrogen storage materials, and new resources. Various metal hydrides are being studied and their hydrogen storage properties being investigated. $\mathrm{MgH}_{2}, \mathrm{FeTi}, \mathrm{LaNi}_{5}$ and $\mathrm{MmNi}_{5}$ are some commonly studied materials.

\subsubsection{Metal Hydrides}

Metal hydrides are promising candidates for many stationary and mobile hydrogen storage applications. Most common use of metal hydrides is as anode material commercial nickel-metal hydrides (Ni-MH) rechargeable batteries ${ }^{[37,38]}$. Metal hydrides have a wide range of applications such as hydrogen compression ${ }^{[39]}$, aircraft fire-detectors ${ }^{[40]}$, isotope separation ${ }^{[41]}$, hydrogenationdisproportionation-desorption-recombination process for the synthesis of magnetic materials such as $\mathrm{Nd}_{2} \mathrm{Fe}_{14} \mathrm{~B}{ }^{[42]}$ and hydrogen getters for microelectronic packages. Research and development is targeted towards two applications: batteries and hydrogen storage. The main advantages of storing hydrogen in metal hydride are the high hydrogen volumetric densities (sometimes higher than in liquid hydrogen) and the possibility to absorb and desorb hydrogen with a small change in hydrogen pressure ${ }^{[43]}$.

Metal hydrides can be defined as a concentrated single phase compound between a host metal and hydrogen ${ }^{[44]}$. Most of the hydrides that could be used for hydrogen storage are metallic in nature ${ }^{[45]}$. Metallic hydrides are formed by transition metals including the rare earth and actinide series. In these hydrides, hydrogen acts as a metal and forms a metallic bond. They have high thermal and electrical conductivities but they are quite brittle. For most uses, the absorption/deposition of hydrogen will have to be done in a small temperature/pressure interval; this is one of the main advantages of metal hydrides over high pressure tanks which show that the system should present a flat plateau and small hysteresis.

A very important problem for practical applications of metal hydride is the fact that the surface of metals is usually covered with oxides of various thicknesses, depending on the formation process of each particular metal. This will most probably be in the case for all industrial means of production of metal hydrides. This oxide layer acts as a hydrogen barrier and must be broken in order for the gaseous hydrogen to access the bare metal. For practical applications, activation is an important factor to take into account while designing the tank system. Filling the tank with activated metal hydrides is difficult since activated alloys are usually more sensitive to air contamination than unactivated metal hydrides.

Magnesium hydride is a classical metal hydride and most widely studied material as it combines a high $\mathrm{H}_{2}$ storage capacity of $7.7 \mathrm{wt} \%$ with the benefit of the low cost of the abundantly available magnesium ${ }^{[46,47,48,49]}$ with good reversibility. Although $\mathrm{MgH}_{2}$ has high hydrogen storage capacity, high decomposition temperature of $300^{\circ} \mathrm{C}$ at $1 \mathrm{bar}$ pressure and poor sorption and desorption kinetics are main drawbacks of this material ${ }^{[50]}$. Tailoring the kinetics and decomposition temperature thus becomes very important from application point of view. Addition of catalysts, altering the particle size by ball milling and alloying with other elements are the methods employed for improving the hydrogen storage properties. Addition of nano-particles of metal catalysts namely palladium, platinum and ruthenium has been experimented and a significant improvement in terms of kinetics of sorption and desorption was observed ${ }^{[51]}$. Ball milling of $\mathrm{MgH}_{2}$ in a planetary ball mill also caused improvement in the kinetics desorption ${ }^{[52]}$. Other than $\mathrm{MgH}_{2}$, magnesium based materials like $\mathrm{Mg}-\mathrm{Ni}, \mathrm{Mg}-\mathrm{Co}, \mathrm{Mg}$ nano composites ${ }^{[53]}$ etc. were also tested for their hydrogen storage behavior. $\mathrm{Mg}_{2} \mathrm{Ni}$ intermetallic showed good kinetics and about $3 \mathrm{wt} \%$ of hydrogen storage capacity ${ }^{[54]}$ whereas $\mathrm{MgNi}_{2}$ did not absorb any hydrogen ${ }^{[55]}$. Mg-Co system with 
Co nanoparticles showed hydrogen storage capacity of 4.5 and $5.4 \mathrm{wt} \%$ respectively for $\mathrm{Mg}_{2} \mathrm{CoH}_{5}$ and $\mathrm{Mg}_{3} \mathrm{CoH}_{5}$. It was also observed that $\mathrm{Co}$ acts as a catalyst and the absorption rate of $\mathrm{Mg}$-Co system was much higher compared to $\mathrm{Mg}$ alone ${ }^{[56]}$. In spite of a large amount of research effort focused on magnesium based materials no success has been achieved to reduce the decomposition temperature suitable for practical purposes. Magnesium based materials have shown excellent cyclic stability but their use is restricted due to the high temperature required and poor kinetics.

$\mathrm{LaNi}_{5}$ is another popular material studied widely. Compared to $\mathrm{MgH}_{2}$, this intermetallic compound shows better hydrogen storage characteristics in terms of kinetics and temperature requirements. But the amount of hydrogen stored is significantly low. At moderate temperature the hydrogen storage capacity of $\mathrm{LaNi}_{5}$ does not exceed $1.4 \mathrm{wt} \%$. Efforts to improve hydrogenation properties by ball milling caused a negative impact. After ball milling the material capacity was reported to be only $0.25 \mathrm{wt} \%{ }^{[57]}$. Other material $\mathrm{MmNi} 4.6 \mathrm{Fe} 0.4$ alloy stored about $1.6 \mathrm{wt} \%$, while MmNi4.6Al0.4 stored $1.3 \mathrm{wt} \%{ }^{[58]}$.

Hydrogen storage properties of $\mathrm{FeTi}$ have been extensively studied. FeTi is a well known hydrogen storage compound with a total hydrogen storage capacity of around $1.90 \mathrm{wt} \%$ with inexpensive elements. Hydrogen capacity of FeTi can be accomplished to $1.90 \mathrm{wt} \%$ by addition of $1 \mathrm{wt} \%$ $\mathrm{Pd}$ as a catalyst ${ }^{[59]}$. However due to the formation of titanium oxide layer the activation of the material is difficult. Both high pressure and high temperature is required to achieve a reproducible absorption/ desorption of the maximum amount of hydrogen in the compound ${ }^{[60,61]}$.

\subsubsection{Complex Hydrides}

Another class of hydrogen storage materials is complex hydrides. These materials have high hydrogen capacities ${ }^{[62]}$. Complex hydrides are salt like materials in which hydrogen is covalently bound to the central atoms, in this way a crystal structure consisting of complex anions is formed. In general the complex hydrides have the formula $\mathrm{A}_{\mathrm{x}} \mathrm{Me}_{\mathrm{y}} \mathrm{H}_{\mathrm{z}}$. Compounds where position A is preferentially occupied by elements of the first and second groups of the periodic table and $\mathrm{Me}$ is in general occupied by boron or aluminium. Complex hydrides are known as "one-pass" hydrogen storage systems which mean that $\mathrm{H}_{2}$ evolves upon contact with water. Sodium, lithium and beryllium are the only elements lighter than magnesium that can also form solid state compounds with hydrogen. The hydrogen content reaches the value of $18 \mathrm{wt} \%$ for $\mathrm{LiBH}_{4}$. Use of complex hydrides for hydrogen storage is challenging because of both kinetic and thermodynamic limitations. Intense interest has developed in low weight complex hydrides such as alanates $\left[\mathrm{AlH}_{4}\right]^{-}$, amides $\left[\mathrm{NH}_{2}\right]^{\text {, }}$, imides and borohydrides $\left[\mathrm{BH}_{4}\right]^{-}$.

In such systems, the hydrogen is often located at the corners of a tetrahedron. The alanates and borates are especially interesting because of their light weight and the capacity for large number of hydrogen atoms per metal atom. Borates are known to be stable and decompose only at elevated temperatures. Alanates are remarkable due to their high storage capacities; however, they decompose in two steps upon dehydriding. Most of these materials have the drawback of high kinetic barriers to dehydrogenation and rehydrogenation in solid state. Any effort to develop complex hydrides as practical hydrogen storage materials requires knowledge of their atomic structure and the thermodynamics of their fundamental hydrogenation and dehydrogenation reaction chemistry. Thus these materials although have a very high hydrogen capacity but suffers from poor kinetics and the desorption temperature are very high, while the conditions required for rehydrogenation are very straight. However, it is known that addition of a dopant or catalyst can modify or tune these materials so as to achieve favourable thermodynamic and kinetic behavior for hydrogen storage applications. Table 3 shows the properties of boron based complex hydrides.

Table 3. Properties of complex boron hydrides ${ }^{[63,64,65,66,67,68]}$

\begin{tabular}{|c|c|c|c|c|}
\hline & $\begin{array}{c}\text { Molecular } \\
\text { weight } \\
(\mathrm{g} / \mathrm{mol})\end{array}$ & $\begin{array}{c}\text { Melting } \\
\text { point } \\
\left({ }^{0} \mathrm{C}\right)\end{array}$ & $\begin{array}{c}\text { Start of } \\
\text { decomposition } \\
\left({ }^{0} \mathrm{C}\right)\end{array}$ & $\begin{array}{c}\text { Hydrogen } \\
\text { content } \\
(\mathrm{wt} \%)\end{array}$ \\
\hline $\mathrm{LiBH}_{4}$ & 21.8 & 275 & $320[54]$ & 18.4 \\
\hline $\mathrm{NaBH}_{4}$ & 37.8 & 505 & $45[55]$ & 10.6 \\
\hline $\mathrm{KBH}_{4}$ & 53.9 & 585 & $584[56]$ & 7.4 \\
\hline $\mathrm{Be}\left(\mathrm{BH}_{4}\right)_{2}$ & 38.6 & -- & -- & 20.7 \\
\hline $\mathrm{Mg}\left(\mathrm{BH}_{4}\right)_{2}$ & 53.9 & -- & $320[57]$ & 14.8 \\
\hline $\mathrm{Ca}\left(\mathrm{BH}_{4}\right)_{2}$ & 69.8 & -- & $360[58]$ & 11.5 \\
\hline $\mathrm{Al}\left(\mathrm{BH}_{4}\right)_{3}$ & 71.4 & -64 & $40[59]$ & 16.8 \\
\hline
\end{tabular}

It can be seen from table that all the boron based complex hydrides have high decomposition temperature. Although they contain large amount of hydrogen the release of hydrogen requires high temperature. The only exception is $\mathrm{Al}\left(\mathrm{BH}_{4}\right)_{3}$, which have such a low melting point that at ambient conditions it is not in solid form. Apart from the high temperature requirement the hygroscopic nature of these materials make them extremely difficult to handle as such special equipment is needed to handle them. Also the materials need to be stored in moisture free inert atmosphere.

Other class of complex hydrides is the hydrides of aluminium. The properties of these materials are tabulated in table 4. Out of these materials only $\mathrm{NaAlH}_{4}$ partially fulfills the requirements for a storage material for mobile fuel cell applications. But for application in a low temperature fuel cell the storage capacity seems to be too low because only the first decomposition step (3.6 wt\%) can be used. Some complex aluminium hydrides are not reversible under acceptable technical conditions. Others have too low hydrogen storage capacities which exclude these materials from broad industrial applications perspective. Similar to the complex hydrides of boron these materials also need special handling. Use of complex chemical hydrides for hydrogen storage, namely the Lithium nitrides, amides and imides have been proposed by Gregory D H ${ }^{[69]}$. It is mentioned that these materials offer high hydrogen storage capacity with reversibility and fast kinetics. 
Table 4. Properties of Complex Aluminium Hydrides ${ }^{[3]}$

\begin{tabular}{|c|c|c|c|c|}
\hline & $\begin{array}{c}\text { Molecular } \\
\text { weight } \\
(\mathrm{g} / \mathrm{mol})\end{array}$ & $\begin{array}{c}\text { Meltin } \\
\text { g point } \\
\left({ }^{0} \mathrm{C}\right)\end{array}$ & $\begin{array}{c}\text { Start of } \\
\text { decompositi } \\
\text { on }\left({ }^{0} \mathrm{C}\right)\end{array}$ & $\begin{array}{c}\text { Hydroge } \\
\mathrm{n} \text { content } \\
(\text { wt\% })\end{array}$ \\
\hline $\mathrm{LiAlH}_{4}$ & 40.0 & - & 170 & 10.6 \\
\hline $\mathrm{NaAlH}_{4}$ & 54.0 & 183 & 230 & 7.5 \\
\hline $\mathrm{KAlH}_{4}$ & 70.1 & -- & $>300$ & 5.8 \\
\hline $\mathrm{Mg}\left(\mathrm{AlH}_{4}\right)_{2}$ & 86.3 & -- & $110-13-$ & 9.3 \\
\hline $\mathrm{Ca}\left(\mathrm{AlH}_{4}\right)_{2}$ & 102.1 & -- & 80 & 7.9 \\
\hline $\mathrm{LiMg}\left(\mathrm{AlH}_{4}\right)_{3}$ & 124.3 & -- & 120 & 9.7 \\
\hline $\mathrm{Li}_{3} \mathrm{AlH}_{6}$ & 53.9 & -- & $165-230$ & 11.1 \\
\hline $\mathrm{Na}_{3} \mathrm{AlH}_{6}$ & 102.0 & -- & 265 & 5.9 \\
\hline $\mathrm{LiMgAlH}_{6}$ & 64.3 & -- & 170 & 9.4 \\
\hline
\end{tabular}

\subsubsection{Amides, Imides and Mixtures}

Chen et al. claimed that $\mathrm{Li}-\mathrm{N}-\mathrm{H}$ system can store high amount of hydrogen up to 10.4 mass \% reversibly [77]. Hydrogenation and dehydrogenation of $\mathrm{Li}_{3} \mathrm{~N}$ were performed by following two-step reversible reactions.

$$
\mathrm{Li}_{3} \mathrm{~N}+2 \mathrm{H}_{2} \longleftrightarrow \mathrm{Li}_{2} \mathrm{NH}_{2}+\mathrm{LiH}+\mathrm{H}_{2} \longleftrightarrow \mathrm{LiNH}_{2}+2 \mathrm{LiH}
$$

But only second step in the reaction is reversible under practical conditions of temperature and pressure and able to release only 5.2 mass $\%$ under practical condition [77, 78]. Thermodynamic properties of the Li-N-H system are unsuitable for practical applications as very high temperature is required to release hydrogen at usable pressure ${ }^{[77]}$. Thus new Li-Mg-N-H system is investigated and developed but reports says from desorption [79-82], absorption ${ }^{[83]}$ and both absorption and desorption reactions [84-86] that the kinetic properties are significantly worse even around $200^{\circ} \mathrm{C}$ than for conventional hydrogen storage alloys. Nanostructure of $\mathrm{Li}_{2} \mathrm{NH}$ shows significantly improved kinetics with decreased absorption and desorption temperature and increased absorption rate ${ }^{[79]}$.

\begin{tabular}{|c|c|c|c|c|}
\hline & $\begin{array}{c}\text { Molecular } \\
\text { weight } \\
(\mathrm{g} / \mathrm{mol})\end{array}$ & $\begin{array}{c}\text { Melting } \\
\text { point } \\
\left({ }^{0} \mathrm{C}\right)\end{array}$ & $\begin{array}{c}\text { Start of } \\
\text { decomposition } \\
\left({ }^{0} \mathrm{C}\right)\end{array}$ & $\begin{array}{c}\text { Hydrogen } \\
\text { content } \\
(\text { mass\% })\end{array}$ \\
\hline $\begin{array}{c}\text { Mixture of } \\
\mathrm{LiAl}\left(\mathrm{NH}_{2}\right) \\
\text { and 4LiH }\end{array}$ & 22.96 & 390 & $130^{\circ} \mathrm{C}$ & More than 5 \\
\hline $\mathrm{LiNH}_{2}$ & 28.897 & & 600 & 8.7 \\
\hline $\mathrm{Li}_{2} \mathrm{NH}$ & 39.01 & 410 & $400-500$ & 3.5 \\
\hline $\mathrm{NaNH}_{2}$ & 56.3502 & 633 & & 7.2 \\
\hline $\mathrm{Mg}\left(\mathrm{NH}_{2}\right)_{2}$ & 72.1232 & & & 5.5 \\
\hline $\mathrm{Ca}\left(\mathrm{NH}_{2}\right)_{2}$ & 720 & \\
\hline
\end{tabular}

Study of different combinations of amide and hydride shows that $\mathrm{Li}-\mathrm{Mg}-\mathrm{N}-\mathrm{H}$ system could be most promising with hydrogen storage capacity of up to 5.5 mass $\%$ and 4 $\mathrm{kg} / 100 \mathrm{~L}$ at temperature range 150 to $200^{\circ} \mathrm{C}$ and absorption pressure less than $10 \mathrm{MPa}$ and desorption pressure more than $1 \mathrm{MPa}^{[88]}$.

\subsubsection{Clathrate Hydrates}

One of currently being investigated material by researches for hydrogen storage is clathrate hydrates. A clathrate is a material consisting of lattice of one type of molecule trapping and containing a second type of molecule. It is water based crystalline solids, physically resembling ice, in which small non-polar molecules are trapped inside cages of hydrogen bonded water molecules. Materials were discovered in 1810 by Sir Humphery Davy. Clathrate hydrates have been found to occur naturally in large quantities ${ }^{[1]}$.

Gas hydrates usually form two crystallographic structures- structure type I and structure type-II and the rarely observed third structure type-H. Dyadin et al. discovered that hydrogen can form clathrate hydrates at high pressure up to $1.5 \mathrm{GPa}{ }^{[89]}$. Mao et al. ${ }^{[90]}$ shows multiple occupancy within cavities of Structure-II hydrate at high pressure up to $300 \mathrm{MPa}$ at $350 \mathrm{~K}$ using high pressure Raman, infrared, X-Ray and neutron studies ${ }^{[90]}$. Mao and Mao suggested that pure hydrogen hydrate is stabilized with double and quadruple occupancy of hydrogen molecules in the small and large cages of sII hydrate with 5.3 mass \% hydrogen storage capacities within the hydrate structure ${ }^{[91]}$. Recently Lokshin et al. [92] reported that $\mathrm{D}_{2}$ molecules only singly occupy the small cages of $\mathrm{D}_{2}$ hydrate. Above studies indicate the possibilities of hydrogen storage in hydrates, the high pressure required for stable structures seem to limit such applications from an economic point of view.

For stabilizing hydrogen in clathrate framework tetrahydrofuran (THF) is used as second guest molecule which results in increasing storage capacity of hydrogen in sII hydrates up to 4 mass $\%{ }^{[93]}$. Rovetto et al. experimentally determined that hydrate structure has the lowest storage capacity for hydrogen when molecular concentration of THF is around $5.6 \mathrm{~mol} \%$ for pressure range 2.5-14.5 $\mathrm{M} \mathrm{Pa}^{[94]}$.

The molecular occupancy and the capacity for storing hydrogen in clathrate hydrates are two important issues in using the material for hydrogen storage. Another extremely important issue for large scale applications for hydrogen storage and transportation concerns the kinetics of formation and decomposition of has hydrates.

\section{Conclusions}

The study of different hydrides shows that, due to their thermodynamic properties it is not recommended to focus on a single material for a global solution of the hydrogen storage problem. It is also well known from other fields of research that the stability and reactivity of small metal clusters are strongly influenced by their size, especially in the size regime below $10 \mathrm{~nm}$, which reveals the new area of storing the hydrogen for practical use. Nanosizing and supporting active hydrogen storage materials has been 
shown, both theoretically and experimentally to greatly benefit hydrogen sorption properties such as release temperature and pressures, loading and charging times and reversibility. Also it has beneficial effects on macroscopic thermal and mechanical stability.

Almost all the materials release hydrogen much above temperature $90^{\circ} \mathrm{C}$. And those which release hydrogen at lower temperature cannot store large quantities of hydrogen. Thus the challenge is to discover, develop or identify a material that can store large quantities of hydrogen and release the same at about $90^{\circ} \mathrm{C}$.

\section{REFERENCES}

[1] Hirsher M. Handbook of hydrogen storage: New materials for future Energy Storage. Weinheim : WILLEY-VCH Verlag GmbH \& Co. KGaA, 2009.

[2] Gupta R B. Hydrogen fuel: Production, transport and storage. Boca Raton : CRC Press, 2008

[3] Vishwanathan B, Scibioh M A,. Fuel Cells. Hyderabad : Univerisity Press, 2006.

[4] Dillon A C, Jones K M, Bekkedahl T A, Kiange C H, Bethune D S, Heben M J. 1997, Storage of hydrogen in single-walled carbon nanotubes. Nature, Vol.386, pp.377-379

[5] Chambers A, Park C R, Baker R T, Rodriguez N M. 1998, Hydrogen Storage in Graphite Nanofibers. J. Phys. Chem. B, Vol. 102, pp.4253-4256.

[6] Zuttel A. 2004, hydrogen Storage Methods. Naturwissenschaften, Vol. 91, pp. 157-172

[7] KOwalczyk P, Holyst R, Terrones M, Terrones H,. 2007, Hydrogen Storage in nanoporous carbon materials: myth and facts. Phys. Chem. Phys, Vol. 9, pp. 1786-1792

[8] Schimmel H G, Kearley G J, Nijkamp M G, Visser C, Jong K, Mudler F M,. 2003, Hydrogen Adsorption in Carbon Nanostructures: Composition of Nanotubes, Fibers, and Coals. Chem. Eur. J, Vol. 9, pp. 4764-4770

[9] Strobe R, Garche J, Moseley P T, Jorisen L, Wolf G,.2006, Hydrogen storage by carbon materials. J. Power Sources, Vol. 159, pp.781-801

[10] Zhou L, Zhou Y P, Sun Y,. Enhanced storage of hydrogen at the temperature of liquid nitrogen. 2004, Int. J. Hydrogen Energy, Vol. 29, pp.319-322.

[11] Yang Z, Xia Y, Mokaya R,. 2007, Enhanced Hydrogen Storage Capacity of High Surface Area Zeolite-like Carbon Materials. J. Am. Chem. Soc., Vol. 129, pp.1673-1679

[12] Kabbour H, Baumann T F, Satcher J H, Sauliner A, Ahn C C,. 2006, Toward New Candidates for Hydrogen Storage: High-Surface-Area Carbon Aerogels. Che. Mater., Vol. 18, pp. 6085-6087

[13] Zuttel A, Sudan P, Mauron P, Kiyobayashi T, Emmenegger C, Schlapbach L,. 2002, Hydrogen storage in carbon nanostructures. Int. J. Hydrogen Energy, Vol. 27, pp. 203-212
[14] Shaijumona M M, Bejoy N, Ramaprabhu S,. Catalytic growth of crabon nanotubes over $\mathrm{Ni} / \mathrm{Cr}$ hydrotalcite-type anionic clay and their hydrogen storage properities. 2005, Appl. Surf. Sci., Vol. 242, pp. 192-198

[15] Jun Jie Niu, Jian Nong Wang, Ying Jiang, Lian Feng Su and Jie Ma. 2007, An approach to carbon nanotubes with high surface area and large pore volume. Microporous and Mesoporous Materials, Vol. 100, pp. 1-5.

[16] Sankarana M, Viswanathana B, Murthy S S,. Boron substituted carbon nanotubes- How appropriate are they for hydrogen storage? 2008, Int J Hydrogen Energy, Vol. 33, pp. 393-403.

[17] Sami-ullah Rather, Renju Zacharia, Sang Woon Hwang, Mehraj-ud-din Naik and Kee Suk Nahm. 2007, Hydrogen uptake of palladium-embedded MWCNTs produced by impregnation and condensed phase reduction method. Chemical Physics Letters, Vol. 441, pp. 393-403.

[18] Ye S H, Gao X P, Liu J, Wang W H, Yuan H T, Song D Y, Zhang Y S,. 1999, Characteristics of mixed hydrogen storage electrode. J. Alloys Compd., Vol. 292, pp. 191-193

[19] Zubizarreta L, Arenillas A, Pis J J,. 2009, Carbon materials for H2 storage. Int. J. Hydrogen Energy, Vol. 34, pp. $4574-4581$.

[20] Luxembourg D, Flamant G, Beche E, Sans J, Girala J, Goetz $\mathrm{V}, .2007$, Hydrogen storage capacity at high pressure of raw and purified single wall carbon nanotubes produced with a solar reactor. Int $\mathrm{J}$ Hydrogen Energy, Vol. 32, pp. 1016-1023.

[21] Ning G Q, Wei F, Luo G H, Wang Q X, Wu Y L, Yu H,. 2004, Hydrogen storage in multi-wall carbon nanotubes using samples up to 85 g. Appl. Phys. A, Vol. 78, pp.955-959.

[22] Weitkamp J, Fritz M, Ernst S,. 1995, Zeolites as media for hydrogen storage. Int. J. Hydrogen Energy, Vol. 20, pp. 967-970

[23] Langmi H M, Walton A, AL-Mamouri M M, Johnson S R, Book D, Speight J D, Edwards P P, Gameson I, Anderson P A, Harris I R,. 2003, Hydrogen adsorption in zeolites A, X, Y and RHO. J. Alloys Comp., Vols. 3560357, pp. 710-715

[24] Harris I R, Walton A, AL-Mamouri M M, Johnson S R, Book D, Speight J D, Edwards P P, Gameson I, Anderson P A, Langmi H M,. 2005, Hydrogen storage in ion-exchanged zeolites. J. Alloys Compd., Vols. 404-406, pp. 637-642.

[25] Vitillo J G, Ricchiardi G, Spoto G, Zecchina A,. 2005, Theoretical maximal storage of hydrogen in zeolitec frameworks. Phys. Chem. Chem. Phys., Vol. 7, pp. 3948-3954

[26] Rameirez-Cuesta A J, Mitchell P C H, Ross D K, Georgiev P A, Anderson P A, Langmi H W, Book D,. 2007, Dihydrogen in cation-substituted zeolites $\mathrm{X}$-an inelastic neutron scattering study. J. Mater. Chem., Vol. 17, pp. 2533-2539

[27] Roswell J L C, Millward A R, Park K S, Yaghi O M,. 2004, Hydrogen Sorption in Functionalized Metal-Organic Frameworks. J. Am. Chem. Soc., Vol. 126, pp. 5666-5667

[28] Li H, Eddaoudi M, O’Keeffe M, Yaghi O M,. 1999, Design and synthesis of an exceptionally stable and highly porous metal-organic framework. Nature, Vol. 402, pp. 276-279. 
[29] Panella B, Hirscher M, P€utter H, M€uller U,. 2006, Hydrogen Adsorption in Metal-Organic Frameworks: $\mathrm{Cu}-\mathrm{MOFs}$ and Zn-MOFs Compared. Adv. Funct. Mater.,Vol. 16, pp. 520-524.

[30] Kaye S S, Daily A, Yaghi O M, Long, J R,. 2007, Impact of Preparation and Handling on the Hydrogen Storage Properties of $\mathrm{Zn} 4 \mathrm{O}(1,4-$-benzenedicarboxylate)3 (MOF-5). J. Am. Chem. Soc., Vol. 129, pp. 14176-14177

[31] Eddaoudi M, Kim J, Rosi N, Vodak D, Watcher J, O'keeffe M, Yaghi O,. 2002, Systematic Design of Pore Size and Functionality in Isoreticular MOFs and Their Application in Methane Storage. Science, Vol. 295, pp. 469-472

[32] Muller U, Schubert M, Teich F, Puetter H, Schierle-Arndt K, Pastre J,. 2006, Metal-organic frameworks-prospective industrial applications. J. Mater. Chem., Vol. 16, pp. 626-636

[33] Chae H K, Siberio-Perez D Y, Kim J, Go Y, Eddaoudi M, Matzger A J, Keeffe M O, Yaghi O M,. 2004, A route to high surface area, porosity and inclusion of large molecules in crystals. Nature, Vol. 427, pp.523-527

[34] Wong-Foy A G, Matzger A J, Yaghi O M,. 2006, Exceptional H2 saturation uptake in Microporous Metal-Organic Frameworks. J. Am. Chem. Soc., Vol. 128, pp. 3494-3495

[35] Furukawa H, Miller M A, Yaghi O M,. 2007, Independent verification of the saturation hydrogen uptake in MOF-177 and establishment of a benchmark for hydrogen adsorption in metal-organic frameworks. J. Mater. Chem., Vol. 17, pp. 3197-3204

[36] Lin X, Jia J H, Zhao X B, Thomas K M, Blake A J, Walker G S, Champness N R, Hubberstey P, Schroder M,. 2006, High H2 Adsorption by Coordination-Framework Materials. Angew. Chem. Int. Ed., Vol. 45, pp. 7358-7364

[37] Fetcenko M A, Ovshinsky S R, Reichman B. et al. 2007, J. Power Sources, 165, 544.

[38] Bauerlein P, Antonius C, Loffler J, et al, 2008, J. Power Sources, 176(2), 547

[39] Wang, X.H., Bei, Y.Y., Song, X.C. et al. (2007) Int. J. Hydrogen Energy, 32 (16), 4011.

[40] Warren, D.E., Faughnan, K.A., Fellows, R.A. et al., 1984, J. Less-common Met., 104, 375.

[41] Sandrock, G. and Bowman, R.C., 2003, J. Alloy. Compd. 356-357, 794

[42] Fruchart, D., Baccmann, M., de Rango, P. et al., 1997, J. Alloy. Compd., 253-254, 121

[43] Reilly, J.J., 1979, Z. Phys. Chem. N. F., 117, 155

[44] Schlapbach, L., Anderson, I., and Burger, J.P., 1994, Hydrogen in metals, in Electronic and magnetic Properties of Metals and Ceramics Part II, Vol. 3B (ed. K.H $>$ Jurgen Buschow), VCH, Weinheim, p.271

[45] Ivey, D.G. and Northwood, D.O., 1983, J.Mater Sci., 18 (2), 321

[46] Zaluska A, Zaluski L, Strom-Oslen J O. 2001, Structure, catalysis and atomic reactions on the nano-scale: a systematic approach to metal hydrides for hydrogen storage. Appl Phys A, Vol. 72, pp.157-165.
[47] Imamura H, Masanari K, Kusuhara M, Katsumoto H, Sumi T, Sakata Y.,. 2005, High hydrogen storage capacity of nanosized magnesium synthesized by high energy ball milling. J Alloys Compds, Vol. \#86, pp. 211-216

[48] Zaluski L, Zalluska A, Strom-Olsen J O.,. 1997, Nanocrystalline metal hydrides. J Alloys Compds, Vols. 253-254, pp. 70-79

[49] Zhu M, Wang H, Ouyang L Z, Zeng M Q, 2006, Composite structure and hydrogen storage properities in $\mathrm{Mg}$-based alloys. Int J Hydrogen Energy, Vol. 31, pp. 251-257.

[50] Sakintuna B, Darkim F L, Hirscher M,. 2007, Metal Hydride Material for Solid Hydrogen Storage: A Review. Int. J. of Hydrogen Energy, Vol. 32, pp. 1121-1140

[51] Xiaochun X, Chaunsan S,. 2006, Improving Hydrogen storage/release properties of Magnesium with Nano-sized Metal Catalyst Measured by Tapered Element Oscillating Microbalance. Appl. Catal., A, Vol. 300, pp. 130-138

[52] Polanski M, Bystrzycki J and Plocinski T,. 2008, The effect of milling conditions on microstructure and hydrogen absorption/desorption properties of magnesium hydride $(\mathrm{MgH} 2)$ without and with $\mathrm{Cr} 2 \mathrm{O} 3$ nanoparticles. Int. J. of Hydrogen Energy, Vol. 33, pp. 1859-1867

[53] Vijay R, Sundaresan R, Maiya M P, Murthy S S, . 2007, Application of nanostructured Mg-x wt $\% \mathrm{MmNi5}$ ( $\mathrm{x}=10-70)$ composites in a hydrogen storage device. Int. J. Hydrogen Energy, Vol. 32, pp. 2390-2399

[54] Gennari F C, Esquivel M R,. 2008, Structural characterization and hydrogen sorption properties of nanocrystalline $\mathrm{Mg} 2 \mathrm{Ni}$. Journal of Alloys and Compounds, Vol. 459, pp. 425-432

[55] Kusadome Y, Ikeda K, Nakamori Y, Orimo s and Horita Z.,. 2007, Hydrogen storage capability of $\mathrm{MgNi} 2$ processed by high pressure torsion. Scripta Materialia, Vol. 57, pp. $751-753$

[56] Shao H, Xu H, Wang Y, Li X,. 2004, Synthesis and hydrogen Storage Behavior of $\mathrm{Mg}-\mathrm{Co}-\mathrm{H}$ system at nanometer scale. J. Solid State Chem., Vol. 177, pp. $3626-3632$

[57] Demircan A, Demiralp M, Kaplan Y, Mat M D, Veziroglu T $\mathrm{N}, .2005$, Experimental and Theoretical analysis of hydrogen absorption in LaNi5-H2 reactors. Int J Hydrogen Energy, Vol. 30, pp. 1437-1446

[58] Muthukumar P. Prakash M M, Murthy S S,. 2005, Experiments on a metal hydride based hydrogen storage device. Int. J. Hydrogen Energy, Vol. 30, pp. 1569-1581

[59] Zaluski L, Zaluska A, Tessier P, Stron-Olsen J O, Schulz R,. 1995, Effects of relaxation on hydrogen absorption in Fe-Ti produced by ball-milling. J Alloys Compds, Vol. 227, pp. $53-57$

[60] Reilly J J, Wiswall R H,. 1974, Formation and properties of iron titanium hydride. Inorg Chem, Vol. 13, pp. 218-222

[61] Bououdina M, Grant D, Walker G.,. 2006, Review on hydrogen absorbing materials- structure, microstructure and thermodynamic properties. Int J Hydrogen Energy, Vol. 13, pp. $177-182$ 
[62] Jain I P, Jain P, Jain A,. 2010, Novel hydrogen storage materials: A review of lightweight complex hydrides. J. Alloys. Compd., Vol. 503, pp. 303-339

[63] Zuttel A, Wenger P, Rentsch S, Sudan P, Mauron P, Emmengger C,. 2003, LiBH4 a new hydrogen storage material. J. Power Sources, Vol. 118, pp. 1-7

[64] Urgnanai J, Torres F J, Palumbo M, Baricco M,. 2008, Hydrogen release from solid state $\mathrm{NaBH}_{4}$. Int $\mathrm{J}$ Hydrogen Energy, Vol. 33, pp. 3111-3115

[65] Orimo S, Nakamori Y, Zuttel A,. 2004, Material properties of MBH4 (M=Li,Na, and K). Mater. Sci. Eng. B, Vol. 108, pp. $51-53$

[66] Chlopek K, Frommen C, Leon A, Zabara O, Fichtner M, 2007, Synthesis and properties of magnesium tetrahydroborate, $\left(\mathrm{MgBH}_{4}\right)$ 2. J. Mater. Chem., Vol. 17, pp. 3496-3503

[67] Ronnebro E, Majzoub E H,. 2007, Calcium Borohydride for Hydrogen Storage: Catalysis and Reversibility. J. Phys. Chem. B, Vol. 111, pp. 12045-12047

[68] Schlesinger H I, Brown H C, Hyde E K,. 1953, The Preparation of Other Borohydrides by Metathetical Reactions Utilizing the Alkali Metal Borohydrides. J. Am. Chem. Soc, Vol. 75, pp. 209-213

[69] Gregory D H. 2008, Lithium Nitrides, Imides and Amides as Lightweight, Reversible Hydrogen Stores. J. Mater. Chem., Vol. 18, pp. 2321-2330

[70] Panella, B., Hirscher, M., and Roth, S. 2005 carbon, 43, 2209-2214

[71] Nijkamp, M.G., Raaymakers, J., Van Dillen, A.J., and de Jong, K.P. 2001 appl, Phys. A, 72, 619-623

[72] Texier-Mandoki, N., Dentzer, J., Piquero, T., Saadallah, S., David, P., and Vix-Guterl, C. 2004 Carbon, 42, 2744-2747

[73] Cho S J. 2002. Fuel Chem. Div. Prepr., 790

[74] Cho S J, Choo K, Kim D P, and Kim J W. 2007. Catal. Today, 120, 336-340

[75] Budd P M, Buttler A, Selbie J, Mahmood K, Mckeown N B, Ghanem B, Msayib k, Book D, and Walton A. 2007 Phys. Chem. Phys., 9, 1802-1808

[76] Ghanem B S, Msayib K J, Mckown N N, Harris K D M, Pan Z, Budd P M, Butler A, Selbie J, Book D, and Walton A. 2007. Chem. Commun., 67-69.

[77] Chen P, Xiong Z, Luo J, Lin J and Tan L. 2002. Nature, 420, 302
[78] Hu, Y.H and Ruckenstein E. 2003. Ind. Eng. Chem. Res., 42, 5135

[79] Luo W. 2004. J. Alloys Compd. 381, 84

[80] Xiong Z, Wu J, Wu G, Chen P, Luo W, Gross K, and Wang J. 2005. J.Alloys Compd. 398, 235

[81] Aoki M, Noritake T, Kitahara G, Nakamori Y, Towata S, and Orimo S. 2007. J.Alloys Compd. 428, 307

[82] Yang J, Sudik A, and Wolverton C. 2007. J. Alloys Compd. 430,334

[83] Ichikawa T, Tokoyoda K, Leng H, and Fuiji H. 2005. J. Alloys Compd. 400, 245

[84] Xiong Z, Wu G, Hu J, Chen P, Luo W, and Wang J. 2006. J.Alloys Compd. 417, 190

[85] Luo W, and Sickafoose S. 2006. J.Alloys Compd. 407, 274

[86] Janot R, Eymery J B, and Tarascon J M. 2007. J. Power Sources, 164, 496

[87] Xie L, Zheng J, Liu Y, Li Y and Li X. 2008. Chem. Mater., 20,282

[88] Dafert F W, and Milklauz R. 1910. Monatsh. Chem.. 31, 981

[89] Dyadin Y A, Larionov G, Aladko E Y, Manakow A Y, Zhurko F V, Mikina T V, Komarow V Y and Grachev E V. 1999. Clathrate formation in water-noble gas (hydrogen) systems at high pressures. J.Struct. Chem., 40, 70.

[90] Mao W L, Mao H K, Gonchrow A F, Struzhkin V V, Guo Q, Hu J, Shu J, Hemley R J, Somayazulu M, and Zhao Y. 2002. Hydrogen clusters in clathrate. Science, 297, 2247.

[91] Mao W L, and Mao H K. 2004. Hydrogen storage in molecular compounds. PNAS. 101, 708

[92] Lokshin K A, Zhao Y, He D, Mao W L, Mao H K, Hemley R J, Lobanow M V, and Greenblatt M. 004. Structure and dynamics of Hydrogen molecules in the novel clathrate hydrate by high pressure neutron diffraction. Phys. Rev. Lett., 93, 125503.

[93] Florusse L J, Peters C J, schoonman J, Hester K C, Koh C A, Dec S F, Marsh K N, and Sloan E D. 2004. Stable low pressure hydrogen clusters stored in a binary clathrate hydrate.

[94] Rovetto L J, Shariati A, Schhnman J, and Peters C J. 2006. Storage of hydrogen in low pressure clathrate hydrates. Proceeding of the $22^{\text {nd }}$ European Symposium on Applied Thermodynamics (ESAT 2006). June 28-July 1. Elsinore, Denmark. 